\title{
An Unusual Splicing Mutation in the HEXB Gene Is Associated with Dramatically Different Phenotypes in Patients From Different Racial Backgrounds
}

\author{
Beth Mclnnes, * Michel Potier, ${ }^{\$}$ Nobuaki Wakamatsu," Serge B. Melancon, ${ }^{\star}$ \\ Maris H. Klavins, * Shoji Tsuji," and Don J. Mahuran *8." \\ ${ }^{*}$ Research Institute, Hospital for Sick Children; ${ }^{\ddagger}$ Service de Génétique Médicale, Hôpital Sainte-Justine, Université de Montréal, \\ Montréal, Québec, Canada; ${ }^{\S}$ Department of Clinical Biochemistry, University of Toronto, Toronto, Ontario, Canada M5G 1 X8; \\ and "Department of Neurology, Brain Research Institute, Niigata University, Niigata, Japan
}

\begin{abstract}
Sandhoff disease is caused by mutations affecting the $\beta$ subunit of lysosomal $\beta$-hexosaminidase (EC 3.2.1.52) and displays a wide spectrum of clinical phenotypes. We report a 57-year-old patient with a very mild phenotype, although residual hexosaminidase $A$ activity in his cultured fibroblasts was $<3 \%$ of normal activity, a level observed in juvenile onset patients. Northern and Western blot analyses confirmed a similar low level of $\beta$ subunit-mRNA and mature $\beta$-protein, respectively. Two mutations of the $H E X B$ gene were identified in this patient, a partial $5^{\prime}$ gene deletion (a null allele), and a $\mathrm{C} \rightarrow \mathrm{T}$ transition 8 nucleotides downstream from the intron 10 /exon 11 junction affecting the splicing of the $\beta$ subunit-mRNA. In their homozygous forms, the $5^{\prime}$ deletion has been previously shown to result in a severe infantile phenotype, and the $C \rightarrow T$ transition in a juvenile phenotype. The genotype and the low level of residual hexosaminidase $A$ activity would be expected to produce a juvenile Sandhoff phenotype in this patient, as well as in four of his six clinically normal siblings. The biochemical basis of his mild phenotype is uncertain, but may result from genetic variations in the RNA splicing machinery. ( $J$. Clin. Invest. 1992. 90:306-314.) Key words: hexosaminidase • Sandhoff disease - $G_{M 2}$ gangliosidosis - lysosomal enzyme • storage disease
\end{abstract}

\section{Introduction}

There are two major $\beta$-hexosaminidase isozymes in normal human tissues, hexosaminidase $\mathrm{A}(\alpha \beta)$ and hexosaminidases $\mathrm{B}$ $(\beta \beta)$. Tay-Sachs disease is caused by mutations in the $H E X A$ gene which encodes the $\alpha$ subunit unique to hexosaminidase A. Sandhoff disease results from $H E X B$ gene mutations which affect the common $\beta$ subunit. Thus, patients with Sandhoff disease have deficiencies of both isoenzymes. The small amount of residual enzyme activity $(<1 \%)$ in tissues of these patients is from the labile $\alpha$ homodimer, $\beta$-hexosaminidase $S$ $(\alpha \alpha)$. The stored substrate responsible for the severe neurological disorders characteristic of hexosaminidase A deficiencies is $\mathrm{G}_{\mathrm{M} 2}$ ganglioside. The $\alpha$ subunit supplies the catalytic site for

Address correspondence to Don J. Mahuran, PhD, The Hospital for Sick Children, Research Institute, 555 University Avenue, Toronto, Ontario, Canada M5G 1 X8.

Received for publication 21 October 1991 and in revised form 10 March 1992

J. Clin. Invest.

(c) The American Society for Clinical Investigation, Inc.

0021-9738/92/08/0306/09 \$2.00

Volume 90, August 1992, 306-314
$\mathrm{G}_{\mathrm{M} 2}$ hydrolysis (assayable with the artificial substrate 4-methylumbelliferone- $\beta$ - $N$-acetylglucosamine-6-sulfate [4-MUGS]) ( 1 ), and the $\beta$ subunit confers stability to the active dimer. The $\beta$ subunit also contains an active site that is primarily responsible for hydrolyzing neutral substrates; e.g., oligosaccharides (assayable with the artificial substrate 4-methylumbelliferone$\beta$ - $N$-acetylglucosamine [4-MUG]) (1) which are stored and/ or excreted in elevated amounts only in Sandhoff disease (reviewed in [2, 3]).

Like other lysosomal storage diseases, Sandhoff disease presents a wide range of clinical phenotypes, from the most severe infantile form (reviewed in [2]) to an adult form in which the primary symptoms are progressive motor neuronopathy (4) (Table I). Sandhoff suggests that as little as $10 \%$ of the normal level of hexosaminidase A is compatible with a normal life; i.e., it represents the "critical threshold" of activity necessary to prevent $G_{M 2}$ storage, and that patients with the infantile onset form lack any residual activity towards $G_{M 2}$ ganglioside. Variations within the $1-10 \%$ range of normal activity may be responsible for the majority of the less severe phenotypes $(2,5,6)$.

There have been more than a dozen mutations in the $H E X A$ gene described (reviewed in [3, 7]). However, only a few $H E X B$ mutations have been characterized. Surprisingly, one of these, a 16-kb deletion of the 5' end, accounted for $27 \%$ of the Sandhoff alleles we analyzed (8). This deletion allele is incapable of transcription due to the absence of the 5 ' promoter region, and in the homozygous form (line GM 294, Table I) produces a severe infantile phenotype (9). A patient with the juvenile phenotype (line GM 2094, Table I) was found to be a genetic compound of the deletion mutation (8) and a $G \rightarrow A$ transition in intron 12. The latter creates an alternate splice site and the inframe insertion of eight codons; i.e., 24 nucleotides $(10,11)$. A third mutation, found in an asymptomatic individual with low enzymatic activity, involves a duplication of a region encompassing the junction of intron 13 and exon 14 . This defect generates an alternate splice site and an inframe insertion of six codons (11). In the juvenile and asymptomatic individuals, a low level of properly spliced $\beta$ subunit-mRNA (which would produce prepro $\beta$-polypeptides with the normal $\beta$-primary structure), produces $3-6 \%$ and $9-10 \%$ of normal hexosaminidase A activity, respectively (11).

Recently, a novel splicing mutation has been identified in a Japanese patient with juvenile Sandhoff phenotype (Japanese patient, Table I). The patient, whose parents were first cousins, was shown to be homozygous for a $\mathrm{C} \rightarrow \mathrm{T}$ transition in exon

1. Abbreviations used in this paper: CRM, cross-reactive material; MCBs, membraneous cytoplasmic bodies; 4-MUG, 4-methylumbelliferone- $\beta$-N-acetylglucosamine; 4-MUGS, 4-methylumbelliferone- $\beta$-Nacetylglucosamine-6-sulfate; PCR, polymerase chain reaction. 
11. This mutation, located eight nucleotides downstream from the intron 10/exon 11 junction, impaired mRNA splicing. Two abnormally spliced transcripts were characterized and shown to produce premature stop codons, which are presumably responsible for their instability (12). A small amount of normally spliced mRNA was detected in the patient's cells. Because of the $\mathrm{C} \rightarrow \mathrm{T}$ transition, the resulting polypeptide contained an amino acid substitution, $\mathrm{PrO}_{417} \rightarrow \mathrm{Leu}$. A second mutation was also found, an $A \rightarrow G$ transition in exon 2 . This mutation, which results in conversion of Lys $_{121} \rightarrow \mathrm{Arg}$, was thought to be a benign polymorphism, for COS cell expression of a $\beta$-cDNA encoding both the $\mathrm{Lys}_{121} \rightarrow \mathrm{Arg}$ and the $\mathrm{Pro}_{417} \rightarrow$ Leu substitutions produced levels of intracellular hexosaminidase B activity similar to that of the wild type cDNA. The authors concluded that the splicing mutation (intron 10/exon $11 \mathrm{C} \rightarrow \mathrm{T}$ transition) alone is responsible for the observed clinical phenotype (12).

In this report, we describe a patient with a very mild disease (line 2557, Table I) whose genotype and low residual enzymatic activity was considered predictive of much more severe juvenile Sandhoff disease. We demonstrate that the patient is a genetic compound of the infantile 5 ' deletion mutation (8) and the juvenile intron $10 /$ exon $11 \mathrm{C} \rightarrow \mathrm{T}$ mutation. The patient's fibroblasts contain $<10 \%$ of normal $\beta$ subunit-mRNA levels and are totally deficient in hexosaminidase B activity; however, they retain $2 \%$ of normal hexosaminidase A activity. Despite these data, this individual is 57 years old and has few clinical symptoms. Enzyme analysis of the patient's six clinically unaffected siblings indicated that four of them (ages 51-62 yr) are also genetic compounds for the same two Sandhoff alleles. The variable phenotype associated with the intron $10 /$ exon $11 \mathrm{C} \rightarrow$ $\mathrm{T}$ transition indicates that other unidentified factors determine the pathological outcome of this mutation. We speculate that the severity of the effect of the mutation on the levels of properly spliced $\beta$ subunit-mRNA may be determined by individual variations in the RNA splicing machinery.

\section{Methods}

Case report. The subject was a 57-yr-old non-Jewish French-Canadian who presented in 1986 with a 9-yr history of severe watery diarrhea, intermittent moderate and diffuse abdominal pain, 17-kg weight loss over a 7-yr period, and increasing weakness. Cholecystectomy was carried out 6 yrs previously without any improvement.

The only other abnormalities found during physical examination were lower limb hyperreflexia and impaired thermal sensitivity of legs and arms. The patient also reported a few episodes of faintness and dizziness, usually improving in the supine position but occasionally leading to syncope, intolerance to warm weather due to impaired sweating, impaired sexual function since 1975 and complete impotence since 1978, and mild urinary incontinence. These findings suggested some impairment of the autonomic nervous system.

Extensive investigations of the gastrointestinal tract carried out between 1980 and 1984 (six hospitalizations), including upper gastrointestinal endoscopy and colonoscopy with biopsies, retrograde cholangiopancreatography, barium studies of the upper gastrointestinal tract, abdominal ultrasound and computed tomographic scan, and extensive hormonal work up, were all normal. $\left[{ }^{14} \mathrm{C}\right] \mathrm{Cholylglycine}$ breath test suggested accelerated intestinal transit speed. ${ }^{14} \mathrm{C}$ excretion peaked early ( $3 \mathrm{~h}$ after ingestion; normal 4-6 h), and its total excretion was $9.3 \%$ of the ingested dose (normal $4 \%$ ).

A rectal biopsy taken at the Hôpital Saint-Lazare, Paris, France in 1986, and reviewed by Pr. Modigliani, showed the presence of membranous cytoplasmic bodies (MCBs) in the intestinal neurons. The patient was referred to the Service de Génétique Médicale, Hôpital Sainte-Justine, Université de Montréal, for further study.

The patient (II-7, Fig. 1) is one of seven siblings. One of his sisters, age 58 (II-3, Fig. 1), has also complained of diarrhea for the last $10 \mathrm{yr}$ and of postural dizziness for $5 \mathrm{yr}$. Clinical investigations similar to those described above were carried out with normal results. There has been no reported change in the state of our patient or any of his siblings during the past $5 \mathrm{yr}$.

Measurements of residual hexosaminidase isozymes and urinary oligosaccharides. Fibroblasts (three T-75 flasks) derived from normal individuals and patients with Sandhoff disease were harvested and lysed in buffer that contained $50 \mathrm{mM}$ Tris- $\mathrm{HCl}$ pH $7.5,10^{-4} \mathrm{M}$ DTT, $10^{-3} \mathrm{M}$ EDTA, and $5 \%$ glycerol within 3 wks of reaching confluence. Protein was determined by the method of Lowry. Separation of the $\beta$-hexosaminidase isozymes (Hex B, Hex A, and Hex S) was accomplished by chromatofocusing and the hexosaminidase activity in each fraction determined by assay with 4-MUG as previously reported (4, $9)$. Alternatively, hexosaminidase $A(\alpha \beta)$ and $B(\beta \beta)$ were separated from hexosaminidase $S(\alpha \alpha)$ by immunoprecipitation with sheep anti$\beta$ antiserum coupled to Protein G Sepharose (Pharmacia Fine Chemicals, Div. of Pharmacia Inc., Piscataway, NJ) as previously described (13). The hexosaminidase A bound to the beads was assayed directly using the $\alpha$-specific substrate 4-MUGS (14). The total precipitated hexosaminidase activity (A and B) was assayed with the common 4MUG substrate. The hexosaminidase isozymes in plasma and leucocytes were assayed with 4-MUG by the thermodenaturation assay method (15). Oligosaccharides in a 24-h urine collection were determined by thin-layer chromatography (16).

Western blot analysis. Samples of cell lysates (Table I) were individually mixed with sample buffer containing 3\% SDS and $25 \mathrm{mM}$ DTT, and incubated at $60^{\circ} \mathrm{C}$ for $15 \mathrm{~min}$. The proteins in each sample were separated by SDS-PAGE using the Laemmli gel system ( $10 \%$ gel) (17). The proteins were transferred to nitrocellulose overnight (13). Nitrocellulose was blocked by exposure to $5 \%$ skim milk in Blotto $10 \mathrm{mM}$ Tris base, $150 \mathrm{mM} \mathrm{NaCl}, 0.05 \%$ Tween $20, \mathrm{pH} 7.5$ ) for $4 \mathrm{~h}$ with gentle shaking, then incubated with a 1:800 dilution ( $1 \%$ skim milk in Blotto) of rabbit anti- $\beta$ IgG, overnight. Nitrocellulose was washed $4 \times$ with $1 \%$ skim milk in Blotto and incubated with a $1: 10,000$ dilution ( $1 \%$ skim milk in Blotto) of goat anti-rabbit IgG/horse radish peroxidase conjugated (Sigma Chemical Co., St. Louis, MO) for $1 \mathrm{~h}$. The nitrocellulose was then washed $4 \times 15$ min with $1 \%$ skim milk in Blotto, quickly rinsed with Blotto (no skim milk), and dried between filter papers. It was then incubated in equal volumes of Detection reagent 1 and Detection reagent 2 (ECL system; Amersham Corp., Arlington Heights, IL) for precisely $1 \mathrm{~min}$, dried briefly on filter papers, covered with Saran wrap, and exposed to Hyperfilm-ECL (Amersham) for $1 \mathrm{~min}$.

Cell culture. Fibroblast cells were cultured in $\alpha$-minimal essential medium (MEM; Flow Laboratories) supplemented with streptomycin, penicillin $(100 \mathrm{mg} / 1 \mathrm{each})$, and $10 \%$ fetal calf serum at $37^{\circ} \mathrm{C}$ under $5 \% \mathrm{CO}_{2}$.

Preparation of genomic DNA. Cultured fibroblast cells, grown to confluency in $6 \times 150 \mathrm{~cm}^{2}$ culture dishes, were harvested in PBS by scraping with a rubber policeman. The cells were centrifuged at 2,000 rpm for $10 \mathrm{~min}$ and the pellet resuspended in $2 \mathrm{ml} \mathrm{TE}$ buffer ( $10 \mathrm{mM}$ Tris- $\mathrm{HCl}, \mathrm{pH} 8 / 1 \mathrm{mM}$ EDTA). An equal volume of TE/0.2\% SDS was added and the tube inverted gently to lyse the cells. The DNA was extracted with phenol, precipitated with ethanol, and resuspended in distilled $\mathrm{H}_{2} \mathrm{O}$ to $0.5 \% \mu \mathrm{g} / \mu \mathrm{l}$ for amplification by polymerase chain reaction (PCR).

Preparation of whole cell RNA. Total cellular RNA was prepared from cultured fibroblast cells by the guanidinium isothiocyanate method ( 18) followed by CsCl ultracentrifugation. Northern blot analysis was carried out as previously reported $(4,9)$.

Reverse transcription of $R N A$. Single-stranded cDNA was prepared from $6 \mu \mathrm{g}$ total cellular RNA by incubation at $42^{\circ} \mathrm{C}$ for $60 \mathrm{~min}$ with 25 $\mathrm{U}$ of avian myeloblastosis virus reverse transcriptase (AMV-RT; Bethesda Research Laboratories, Gaithersburg, MD), 5 U of RNAguard $^{\mathrm{TM}}$ (Pharmacia. LKB Biotechnologies) and $0.5 \mu \mathrm{g}$ oligo-dT in 50 
$\mu \mathrm{l}$ vol of $0.1 \mathrm{M}$ Tris- $\mathrm{HCl}$ ( $\mathrm{pH} 8.3$ ), $140 \mathrm{mM} \mathrm{KCl}, 10 \mathrm{mM} \mathrm{MgCl}_{2}, 28$ $\mathrm{mM} \beta$-mercaptoethanol, $0.5 \mathrm{mM}$ each of four dNTP's. The cDNA was precipitated by the addition of $1 / 10$ vol $3 \mathrm{M}$ sodium acetate ( $\mathrm{pH} 4.8$ ) and 2 vol of absolute ethanol, vacuum desiccated, and resuspended in $50 \mu \mathrm{l}$ sterile distilled $\mathrm{H}_{2} \mathrm{O}$ for amplification by PCR.

$P C R$. Amplification of exonic and intron/exon junctions from genomic DNA, and CDNA segments was performed by the PCR procedure, using the oligonucleotide primers as described previously (12). The reactions were performed in $100 \mu \mathrm{l}$ vol containing $0.1-0.5 \mu \mathrm{g}$ genomic DNA or $2 \mu \mathrm{ldDNA}, 10 \mathrm{mM}$ Tris- $\mathrm{HCl}$ ( $\mathrm{pH} 8.3$ ), $50 \mathrm{mM} \mathrm{KCl}, 1.5$ $\mathrm{mM} \mathrm{MgCl} 2,0.01 \%$ gelatin, $200 \mu \mathrm{M}$ each of four dNTP's, $0.5 \mu \mathrm{g}$ of each primer and $2.5 \mathrm{U}$ AmpliTaq $^{\mathrm{TM}} \mathrm{Taq}$ polymerase. Amplification was achieved by incubation in a DNA Thermal Cycler ${ }^{\mathrm{TM}}$ (Perkin Elmer Cetus Instrs., Norwalk, CT) for 30 cycles, each consisting of a denaturation step at $94^{\circ} \mathrm{C}$ for $30 \mathrm{~s}$, an annealing step at $55^{\circ} \mathrm{C}-65^{\circ} \mathrm{C}$ ( usually at $5^{\circ} \mathrm{C}$ below the melting temperature (Tm) of the primers) for $30 \mathrm{~s}$ and an extension step at $72^{\circ} \mathrm{C}$ for $1.5-3 \mathrm{~min}$ (depending on the length of DNA to be amplified ). 1/ 10th of the amplified products were analyzed by agarose gel electrophoresis. All splice junctions and exonic sequences of the $H E X B$ gene from cultured fibroblasts of patient 2557 were amplified and sequenced.

The region around exon 11, found to be heterozygous for the $\mathrm{PrO}_{417} \rightarrow$ Leu mutation in genomic DNA was amplified by PCR using oligonucleotides " 528 " ( 3 ' intron 9, sense; 5'-CACCTCTCAAAATGCAAGAA-3') and " 529 " (5', intron 11, antisense; 5'-AATGGTTGCTTCACTTACCA-3'). Oligonucleotide " 52 " (5'-CTCCAATCTTGTCCATAGCT-3') was used as a primer for direct sequencing. A fragment of CDNA containing this region of exon 11 was amplified by PCR using primers "18" (sense; 5'-TGTTGGGAATCAAATCCAAAA-3') and "13" (antisense; 5'-CAGTCTGTCATAGGCGTCAT-3').

Genomic DNA from fibroblasts of a normal control and the subject was amplified by PCR using oligonucleotides " $2-1$ " ( 3 ' intron 1, sense; 5'-GAGTTAACTACAATGTTACTAG-3') and " $2-2$ " (5', intron 2, antisense; 5'-GGAAGCTTAATAGGAATCATAAACTC-3'; a Hind III site in the primer is underlined) in the region of exon 2 where the Japanese patient was previously reported to have a second $\mathrm{Lys}_{121} \rightarrow$ Arg substitution, as well as the same Pro $_{417} \rightarrow$ Leu mutation (12) we now report in our patient, 2557 (see Results). The product was sequenced directly using oligonucleotide 2-1 as primer. An area in exon 6 of genomic DNA from our patient, line 2557, was amplified and directly sequenced with primers " 891 " ( 3 ', intron 5 , sense; 5'-AGACATATGGAAGGAATTCCAA- ${ }^{\prime}$; an EcoRI site in the primer is underlined ) and " 892 " (5', intron 6, antisense; 5'-AACTTGTAATGAAACTATACCCA-3'). cDNA was amplified in this region by PCR with primers "15" (sense; 5'-GGTTTCTACAAGTGGCATCA-3') and "10" (antisense; 5'-ATGTTGTATTCAGAGTAGGG-3').

Direct sequencing. In preparation for sequencing, DNA amplified by PCR was purified from unincorporated primers and extraneous bands by electrophoresis in an $8 \%$ polyacrylamide gel. The DNA was excised and eluted overnight with shaking incubation at room temperature in distilled $\mathrm{H}_{2} \mathrm{O}$. DNA was freed of traces of acrylamide by passage through siliconized glass wool and precipitated twice by addition of $1 / 10$ vol sodium acetate ( $\mathrm{pH} \mathrm{4.8)}$ and 2 vol absolute ethanol.

DNA was resuspended in $10 \mu$ distilled $\mathrm{H}_{2} \mathrm{O}$. Direct sequencing was performed on 2-5 $\mu$ l samples with [ $\left.\alpha^{35} \mathrm{~S}\right] \mathrm{dATP}$ using a modification of the Sequenase ${ }^{\mathrm{TM}}$ protocol (United States Biochemical Corp. Cleveland, $\mathrm{OH}$ ), by supplementing all buffers with $10 \%$ DMSO and 50 $\mu \mathrm{M} \mathrm{NaCl}$, as described by Winship (19). Samples were electrophoresed in $6 \%$ polyacrylamide/urea gels.

\section{Results}

The identification of MCBs in the patient's intestinal neurons led to the investigation of residual hexosaminidase levels (by the standard thermodenaturation assays [15]) in plasma (Fig. 1). The results indicated that he, as well as four of his six sib-

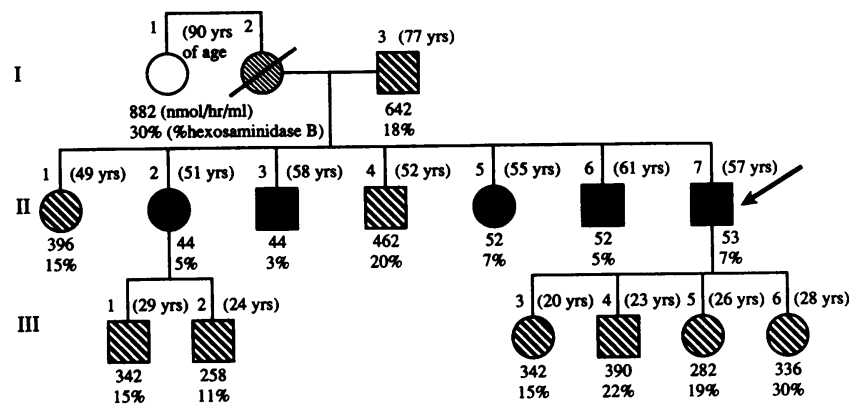

Figure 1. Pedigree of the subject (arrow) and his family. Ages in years, total plasma hexosaminidase activity, and the percent of the activity that is heat stable, (i.e., hexosaminidase B) is given for each family member. Based on these assays, each individual is assigned a status, i.e., normal (open symbol), carrier of one mutant $H E X B$ allele (striped symbol), and carrier of two mutant $H E X B$ alleles (solid symbol). The mother of our patient ( $\mathrm{I}-2)$ is deceased, but is assumed to have been a carrier, thus the different striped pattern. Normal mean $=822 \mathrm{nmol} / \mathrm{h}$ per $\mathrm{ml}$ (total plasma hexosaminidase activity, 4-MUG); and $26 \%$ hexosaminidase B; normal range $=552-1374$ $\mathrm{nmol} / \mathrm{h}$ per $\mathrm{ml}$, and $18-31 \%$ hexosaminidase B (by thermodenaturation).

lings, had total hexosaminidase levels within the range of patients with Sandhoff disease. Of these siblings, only II- 3 has shown some symptoms similar to those of our patient (see case report); the others were asymptomatic.

The above activity data led to a more quantitative evaluation of the hexosaminidase isozymes in fibroblasts (line 2557) from our patient, as well as an estimation of the relative steady state level of mature (i.e., lysosomal, $\beta$ subunit protein [Western blot]). These data were compared to those obtained from the fibroblasts of other patients with known genotypes and phenotypes (GM 2094, juvenile; 2400, adult; 2399, adult; and GM 294 infantile; Table I). The chromatofocusing separation of the hexosaminidase isozymes from four of these cell lines (2557, GM 294, GM 2094, and 2400) is shown in Fig. 2. The isozyme pattern from our patient's cell lysate was virtually identical to that of cell line GM 2094 from the juvenile Sandhoff patient. Both of these lines clearly produced more residual hexosaminidase A than did the infantile/deletion line, GM 294, and less than the cell line from the adult Sandhoff patient, 2400 . The quantitation of the enzymatic activity levels is presented in Table II (Chromatofocusing). These results were corroborated by a solid state assay that selectively immunoprecipitates hexosaminidase $\mathrm{A}$ and $\mathrm{B}$, but not hexosaminidase $\mathrm{S}(\alpha \alpha)$, with an anti- $\beta$ antiserum (20), and then quantitates both isozymes using the common 4-MUG substrate, or quantitates hexosaminidase A alone using the $\alpha$-specific 4-MUGS as a substrate (Table II, Immunoprecipitation). Mature $\beta$ subunits contained in lysates from all four patients' fibroblasts were undetectable when compared with similar amounts of total protein from a normal cell lysate (data not shown). However, when the amount of lysate protein loaded from the patients' cells was increased 20-100-fold over that loaded from the normal cell lysate, mature $\beta$ protein in the $28-\mathrm{kD}$ range (13) was detectable (Fig. 3). As was the case with the enzymatic activity, when the variation in total protein load was taken into account similar amounts of $\beta$ protein were present in lysates from our patient's cells and those from line GM 2094, larger amounts 
Table I. Summary of Clinical, Biochemical, and Genetic Data

\begin{tabular}{|c|c|c|c|c|c|}
\hline $\begin{array}{l}\text { Cell line phenotype } \\
\text { references }\end{array}$ & $\begin{array}{l}\text { GM } 294 \\
\text { infantile } \\
(8,9)\end{array}$ & $\begin{array}{l}\text { GM } 2094 \\
\text { juvenile } \\
(5,8-11)\end{array}$ & $\begin{array}{c}2400 / 2399 \\
\text { (sisters) } \\
\text { adult } \\
(4,8)\end{array}$ & $\begin{array}{c}2557 \text { (subject) } \\
\text { novel } \\
\text { (8, this report) } \\
\end{array}$ & $\begin{array}{l}\text { Japanese patient } \\
\text { juvenile } \\
\text { (12) }\end{array}$ \\
\hline MCBs in: & & Peripheral nerve axons & Appendiceal ganglion & Rectal biopsy & Rectal biopsy \\
\hline & $++++^{*}$ & + & + & + & + \\
\hline $\begin{array}{l}\text { Oligosaccharide } \\
\text { excretion }\end{array}$ & $++++^{*}$ & ++ & + & - & ++ \\
\hline \multicolumn{6}{|l|}{ Involvement } \\
\hline Motor neurons & $++++^{*}$ & NR & + & - & - \\
\hline Neurological & $++++^{*}$ & +++ & + & - & + \\
\hline Autonomic nerves & NR & NR & + & + & + \\
\hline \multicolumn{6}{|l|}{ Residual Hex A } \\
\hline Fibroblasts & $0 \%$ & $2.5 \%$ & $21 \%$ & $2.4 \%$ & $8 \% \ddagger$ \\
\hline \multicolumn{6}{|l|}{ Mutations } \\
\hline Allele \#1 & $\begin{array}{l}16 \mathrm{~kb} \text { deletion } \\
\mathrm{C} \rightarrow \mathrm{G} \text { exon } 6^{8}\end{array}$ & $\begin{array}{l}16 \mathrm{~kb} \text { deletion } \\
\mathrm{C} \rightarrow \mathrm{G} \text { exon } 6^{8}\end{array}$ & $\begin{array}{l}16 \mathrm{~kb} \text { deletion } \\
\mathrm{C} \rightarrow \mathrm{G} \text { exon } 6^{8}\end{array}$ & $\begin{array}{l}16 \mathrm{~kb} \text { deletion } \\
\mathrm{C} \rightarrow \mathrm{G} \text { exon } 6\end{array}$ & $\begin{array}{l}\mathrm{C} \rightarrow \mathrm{T} \text { exon } 11 \\
\mathrm{~A} \rightarrow \mathrm{G} \text { exon } 2^{* *}\end{array}$ \\
\hline Results & Null allele & Null allele & Null allele & Null allele & $\begin{array}{l}\text { Misspliced, unstable } \\
\text { mRNA }\end{array}$ \\
\hline mRNA & None & None & None & None & Reduced levels \\
\hline $\begin{array}{l}\text { Mature } \beta \text {-CRM } \\
\text { Substitution(s) }\end{array}$ & None & None & None & None & $\begin{array}{l}\text { Reduced levels' } \\
\text { Pro }_{417} \rightarrow \text { Leu }^{\prime \prime} \\
\text { Lys }_{121} \rightarrow \text { Arg }^{* *}\end{array}$ \\
\hline Allele \#2 & $\begin{array}{l}16 \mathrm{~kb} \text { deletion } \\
\mathrm{C} \rightarrow \mathrm{G} \text { exon } 6^{5}\end{array}$ & $\mathrm{G} \rightarrow \mathrm{A}$ intron 12 & Not determined & $\begin{array}{l}C \rightarrow T \text { exon } 11 \\
(\text { no exon } 2 A \rightarrow G)\end{array}$ & $\begin{array}{l}\mathrm{C} \rightarrow \mathrm{T} \text { exon } 11 \\
\mathrm{~A} \rightarrow \mathrm{G} \text { exon } 2^{* *}\end{array}$ \\
\hline Results & Null allele & $\begin{array}{l}\text { Misspliced stable } \\
\text { mRNA }\end{array}$ & & $\begin{array}{l}\text { Misspliced unstable } \\
\text { mRNA }\end{array}$ & $\begin{array}{l}\text { Misspliced unstable } \\
\text { mRNA }\end{array}$ \\
\hline mRNA & None & Normal levels & Normal levels & Reduced levels & Reduced levels \\
\hline $\begin{array}{c}\text { Mature } \beta \text {-CRM } \\
\text { Substitution(s) }\end{array}$ & None & $\begin{array}{l}\text { Reduced levels' } \\
\text { None', i.e., normal } \\
\text { primary structure' }\end{array}$ & $\begin{array}{l}\text { Reduced levels } \\
\text { Not determined }\end{array}$ & $\begin{array}{l}\text { Reduced levels' } \\
\text { Pro }_{417} \rightarrow \text { Leu }^{\prime \prime}\end{array}$ & $\begin{array}{l}\text { Reduced levels' } \\
\text { Pro }_{417} \rightarrow \text { Leul }^{\prime \prime} \\
\text { Lys }_{121} \rightarrow \text { Arg** }^{* *}\end{array}$ \\
\hline
\end{tabular}

NR, not reported. * Based on the classical infantile Sandhoff phenotype (Table III, reference 4). ${ }^{\ddagger}$ This value was determined by Wakamatsu et al. (12). " Indicate the highly probable, but experimentally unproven presence of the mutation. "Demonstrated by Wakamatsu et al. not to affect the function of the $\beta$-protein (12). 'Translated from a small amount of properly spliced $\beta$ subunit mRNA. ${ }^{* *}$ Demonstrated in this report and by Wakamatsu et al. to be a normal polymorphism (12).

were found in line 2400 , and no $\beta$ protein was detected in the deletion line GM 294.

The enzymatic and Western blotting data indicated the presence of mutation(s) in the patient's $H E X B$ gene. In order to predict the type of mutation(s) that could be present we determined the levels of $\alpha$ and $\beta$ subunit-mRNA in the patient's fibroblasts by Northern blotting. Fig. 4 (panels “ $\beta$ Hexosaminidase, $\alpha$-chain" and " $\beta$-Glucuronidase") demonstrates that levels of $\alpha$-mRNA transcribed by the $H E X A$ gene and the control mRNA (encoding $\beta$-glucuronidase (21) were similar in the patient's cell line (lane 4 ), those of the normal control (lane 1), and those from two sisters with adult onset Sandhoff disease (lines 2399 and 2400; lanes 2 and 3) (4). However, the level of $\beta$ subunit-mRNA in our patient's cells was decreased to less than $10 \%$ of normal levels (Fig. $4, \beta$-Hexosaminidase, $\beta$-chain, lane 4 ). We initially determined that our patient (line 2557) and the adult Sandhoff patients are heterozygous for the common partial 5 ' end deletion mutation (8). As we have noted (8), Northern blotting at the level of exposure seen in Fig. 4 cannot detect differences in levels $\geq 50 \%$ of normal mRNA; i.e., the adult-onset patients appear to have normal levels of $\beta$ subunit-mRNA. However, the severely reduced level of $\beta$ subunit-mRNA in our patient's cells, which is similar to the levels of residual enzymatic activity and $\beta$-crossreactive material (CRM), suggest that his second allelic mutation primarily exerts its detrimental effect by lowering the level of $\beta$ subunit-mRNA.

In order to identify the patient's second $H E X B$ gene mutation, all exons and intron/exon junctions from his genomic DNA were amplified by PCR and the resultant DNA sequenced directly. Only two changes from the normal sequence were found, both in a heterozygous form. The first was a $\mathrm{C} \rightarrow$ $\mathrm{G}$ transition in the codon for $\mathrm{Ser}_{243}$ in exon 6, which would result in its substitution by $\mathrm{Cys}$ (data not shown). The second was a $\mathrm{C} \rightarrow \mathrm{T}$ transition in the codon for $\mathrm{Pro}_{417}$ in exon 11 (Fig. 5). This transition was the same mutation found in a homozygous form in cells from the Japanese juvenile Sandhoff patient with reduced $\beta$ subunit mRNA levels (Table I). We suspected the intron 10 /exon $11 \mathrm{C} \rightarrow \mathrm{T}$ transition to be directly responsible for the lower $\beta$ subunit mRNA levels in our patient. The $C \rightarrow G$ transition in exon 6 could result in a silent polymorphism or be present on the exon 1-5-deleted allele. 


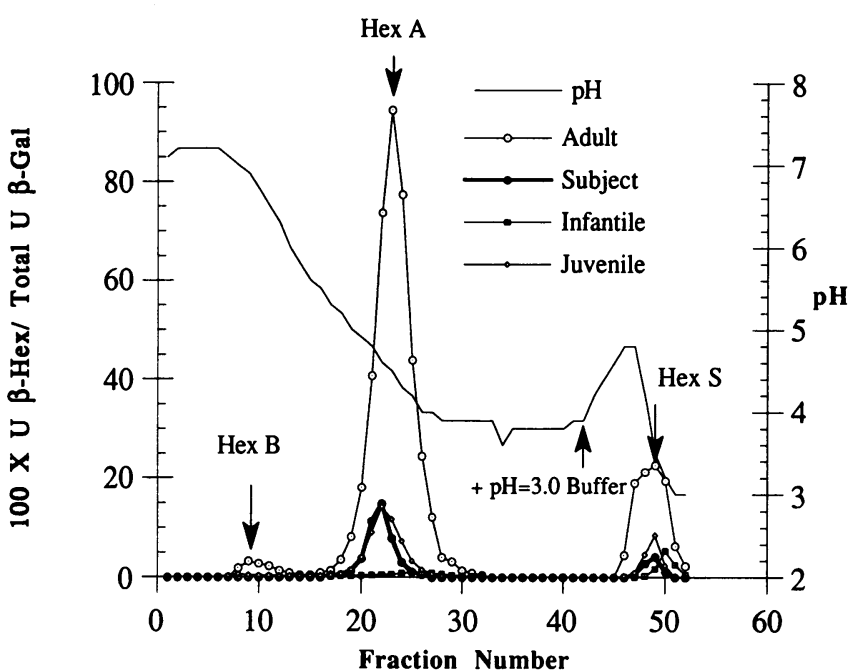

Figure 2. Chromatofocusing elution profiles of the hexosaminidase isozymes; activities were obtained from total fibroblast extracts. The nmol of 4-MUG hydrolysed per $h$ in each fraction were normalized as described in (9), by dividing each value by the total number of units of $\beta$-galactosidase activity contained in the cell extract applied to the column $(\times 100)(9)$. These values were plotted versus the fraction number. Small open circles represent the separation of isozyme from one of two previously described adult onset Sandhoff patients, cell line 2400 (4), open squares represent the infantile deletion line GM 294, juvenile onset line GM 2094 is represented by open diamonds, and closed circles represent the subject of this report (to compare these patterns with those obtained for fibroblasts derived from normal and carrier individuals see reference [9]).

To determine if the $\mathrm{C} \rightarrow \mathrm{G}$ transversion in exon 6 and/or the $\mathrm{C} \rightarrow \mathrm{T}$ transition in exon 11 were transcribed, we analyzed the nucleotide sequences of our patient's cDNA in the regions of the two substitutions. Amplification of the region encompassing the exon 6 transition produced a single fragment of the expected length (data not shown). Direct sequencing of this fragment showed that it contained only the nucleotide needed to code for the wild type Ser residue (data not shown). Thus, the $\mathrm{C} \rightarrow \mathrm{G}$ transition is not transcribed and must reside in exon 6 of the partially deleted allele. On the other hand, amplifica-

Table II. Activities of the Hexosaminidase Isozymes in Various Affected Fibroblast Cell Lines

\begin{tabular}{|c|c|c|c|c|c|c|}
\hline \multirow{3}{*}{$\begin{array}{l}\text { Cell } \\
\text { line }\end{array}$} & \multirow[b]{3}{*}{ Phenotype } & \multicolumn{3}{|c|}{ Chromatofocusing } & \multirow{2}{*}{\multicolumn{2}{|c|}{$\frac{\text { Immunoprecipitation }}{\% \text { Normal }^{8}}$}} \\
\hline & & \multicolumn{2}{|c|}{$\%$ Normal $^{*}$} & \multirow{2}{*}{$\begin{array}{l}\text { Units } \\
\text { Hex S }\end{array}$} & & \\
\hline & & Hex B & Hex A & & Hex A & $\operatorname{Hex} A+B$ \\
\hline GM 294 & Infantile & 0 & 0 & 70 & 0 & 0 \\
\hline GM 2094 & Juvenile & 0 & 2.5 & 31 & 2.5 & 1.1 \\
\hline 2557 & Subject & 0 & 2 & 16 & 2.7 & 1.2 \\
\hline 2400 & Adult & 2.1 & 25 & 200 & 16.8 & 10 \\
\hline
\end{tabular}

* Percentage of normal hexosaminidase B (Hex B) or hexosaminidase A (Hex A) activity after fractionation by chromatofocusing using 4-MUG as a substrate (9).

${ }^{\ddagger}$ nmol 4-MUG/h per mg hydrolyzed by hexosaminidase $\mathrm{S}$ (Hex S) after fractionation by chromatofocusing (9).

\$ Immunoprecipitated Hex A and B assayed with Hex A-specific 4-MUGS (Hex A) or the common 4-MUG (Hex A + B) substrates, presented as \% of normal activity.

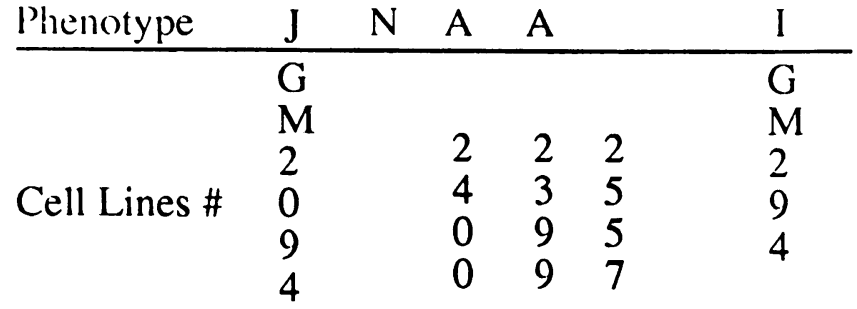

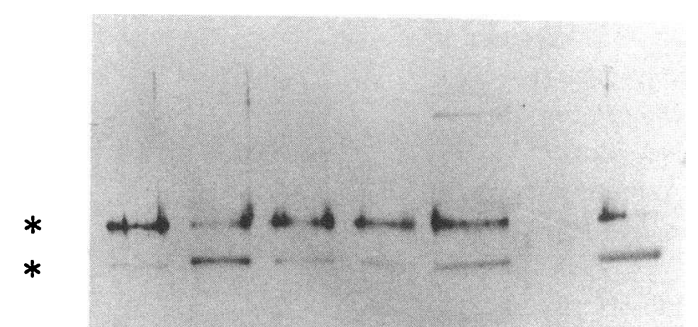

\section{Protein}

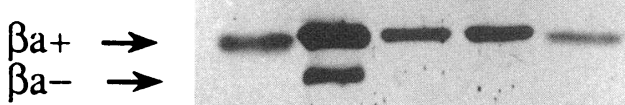

Loaded $(\mu \mathrm{g}): 100 ; 1.4 ; 25 ; 50 ; 140 ; 0 ; 100$

Figure 3. Western blot of fibroblast cell lysates; the amount of total lysate protein $(\mu \mathrm{g})$ from each cell line that was loaded onto the gel is indicated at the bottom. Extracts were (left to right) from; cell line GM 2094 from a patient with juvenile onset Sandhoff disease $(J)$; a normal control $(N)$; cell lines 2400 and 2399 from two sisters with adult onset Sandhoff disease $(A)$; cell line 2557 from our patient (the subject of this report); and line GM 294 from an infantile onset patient $(I)$ homozygous for the deletion mutation (negative control). The positions of the most antigenic $\beta$-polypeptide in the mature $\beta$ subunit, $\beta_{\mathrm{a}}(28 \mathrm{kD})(13)$, with $\left(\beta_{\mathrm{a}}+\right)$ or without $\left(\beta_{\mathrm{a}}-\right)$ its single oligosaccharide (33), are indicated. Two nonspecific bands present in the negative control are marked with *. Note that the mutant pro $\beta$ protein ( $>97 \%$ of that translated) in line GM 2094 contains an 8 amino acid insertion. This protein is trapped and degraded in the endoplasmic reticulum (11).

tion of the region containing the $\mathrm{C} \rightarrow \mathrm{T}$ transition at the codon for $\mathrm{Pro}_{417}$ produced three major fragments (Fig. 6). One, at 425 bp (P1) was the expected size for properly spliced $\beta$ subunitmRNA. The other two, $313 \mathrm{bp}$ (P2) and $255 \mathrm{bp}$ (P3), were similar in size to the two abnormally spliced $\beta$ subunit-mRNA species described in fibroblasts from the Japanese patient (12). P1 was confirmed to be normally spliced $\beta$ subunit-mRNA by direct sequencing. Its sequence contained only the mutant " $T$ " nucleotide at the codon for $\mathrm{Pro}_{417}$ (Fig. $7 \mathrm{~A}$ ). As was the case with the Japanese juvenile Sandhoff patient (12), P2 displayed a sequence corresponding to exon 10 spliced to a cryptic site mid-way in exon 11 (a TGA premature stop codon is generated six nucleotides after the junction (Fig. $7 B$ ) and P3 displayed the sequence of exon 10 spliced directly to exon 12 (Fig. $7 B$ ) (a premature stop codon would be generated 171 nucleotides after the junction ).

The cloned genomic DNA from the Japanese juvenile Sandhoff patient was also reported to contain a point mutation that would result in a Lys $_{121} \rightarrow$ Arg substitution (Table I); evidence was presented that this most likely represents a nor- 


\section{B - Hexosaminidase}
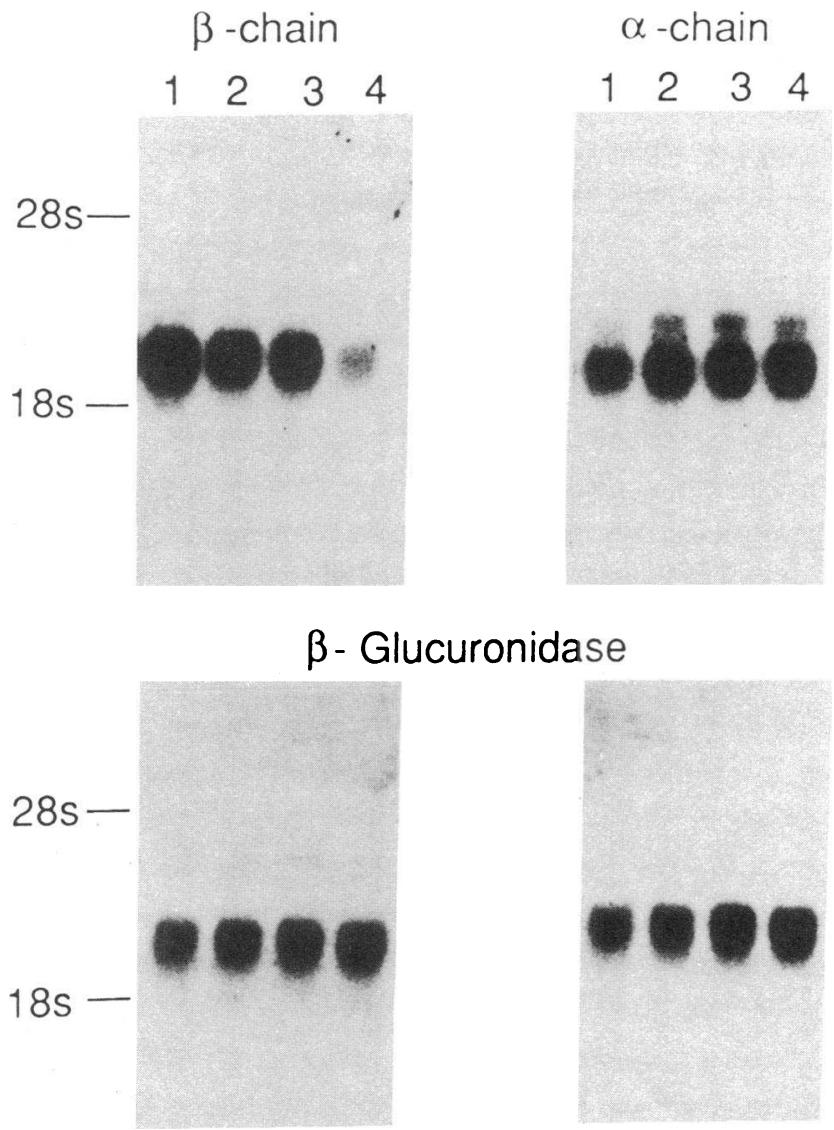

Figure 4. Northern blot analysis of total RNA; a normal control, lane 1; two sisters with adult onset Sandhoff disease (lines 2400 and 2399), lanes 2 and 3; and our patient (line 2557), lane 4. The blots were probed with labeled cDNAs encoding; the prepro $\beta$-chain and prepro $\alpha$-chain of $\beta$-hexosaminidase, and $\beta$-glucuronidase.

mal polymorphism (12). To determine if our patient also harbored this mutation, we amplified genomic DNA from line 2557 and from normal control leukocytes in the affected region of exon 2. As shown by the sequence analysis in Fig. 8, DNA from our patient contains only the normal Lys codon 121 (Fig. 8, Patient). Surprisingly, one of the $H E X B$ alleles from a normal control was found to contain the Arg codon substituted at position 121 (Fig. 8, Normal). Fresh serum and leukocytes were isolated from the blood of the control individual (R.T.), and they both were tested for total hexosaminidase activity and percentage of hexosaminidase $B$ ( of the total) by the thermodenaturation assay $(22,23)$. The results from both sources of enzyme were in the normal range (Table III). These data confirm that the Lys ${ }_{121} \rightarrow$ Arg substitution is a normal polymorphism. Furthermore, they suggest that the intron 10/exon 11 $\mathrm{C} \rightarrow \mathrm{T}$ transition mutation in our patient's and the Japanese patient's $H E X B$ genes have arisen independently.

\section{Discussion}

Determination of our patient's genotype revealed that he is a compound heterozygote for two mutant $H E X B$ alleles. One of

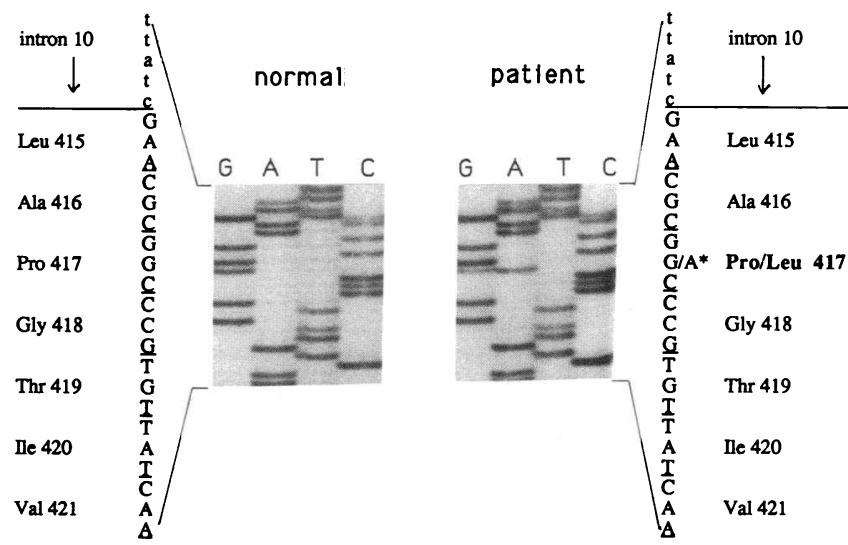

Figure 5. Autoradiogram of a $6 \%$ polyacrylamide/urea gel showing anti-sense sequence obtained for genomic DNA; from a normal individual and from patient 2557 at the intron 10 /exon 11 junction. $\mathrm{Pa}$ tient 2557 is heterozygous for a $\mathrm{C} \rightarrow \mathrm{T}$ transition at the codon for Pro $_{417}$ in exon 11 (indicated by ${ }^{*}$ as a G $\rightarrow$ A transition in the antisense sequence). This results in the substitution of a Leu codon.

these we previously reported to be the common Sandhoff $5^{\prime}$ deletion allele which is not transcribed (8). Direct sequencing of PCR fragments from genomic DNA and cDNA revealed that the mutation in our patient's second $H E X B$ allele is a $\mathrm{C} \rightarrow$ $T$ transition 8 nucleotides downstream from the intron $10 /$ exon 11 junction (Fig. 5). This mutation in the homozygous form was shown to impair $\beta$ subunit-mRNA splicing in a Japanese patient with juvenile onset Sandhoff disease (12). The accompanying amino acid substitution, $\mathrm{PrO}_{417} \rightarrow$ Leu was shown to be a neutral change. It was demonstrated to have no detrimental effects on hexosaminidase B activity in transfected COS cells, and quantitation of the $\beta$-mRNA ( $8 \%$ of normal) correlated with the residual $8 \%$ activity level found in the Japanese patient's fibroblasts (12). However, amplification of this region of our patient's cDNA produced three fragments (Fig. $6)$. The largest represented the properly spliced $\beta$ subunit-

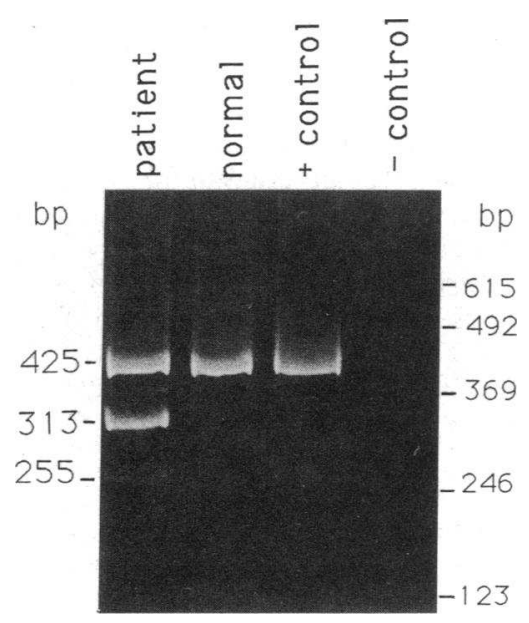

Figure 6. 8\% polyacrylamide gel showing PCR-amplified cDNA samples; from the patient 2557 and a normal individual. cDNA was prepared by reverse transcription of mRNA from cultured fibroblasts of a normal line and of patient 2557. cDNA from the plasmid pCD $\beta 43$ ( + control) and a reagent blank ( - control) were amplified in the same manner. The cDNA products from the normal cells ( $425 \mathrm{bp}$ ) and from the patient cells ( $425 \mathrm{bp}, 313 \mathrm{bp}$ and $255 \mathrm{bp}$, as shown on the left) were subsequently acrylamide gel-purified and directly sequenced. Basepair sizes of the $123 \mathrm{bp}$ DNA ladder (BRL) are indicated on the right. 

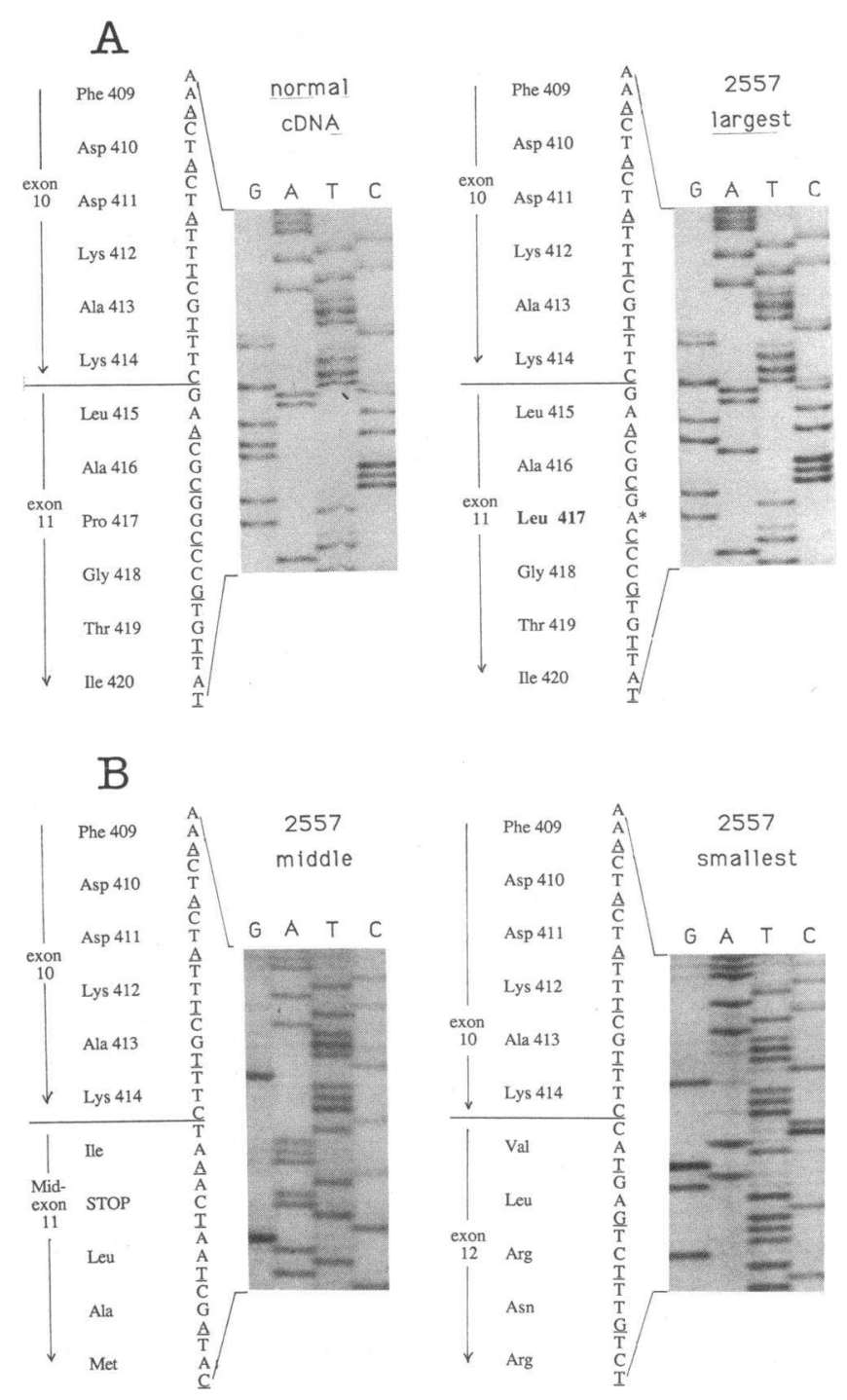

Figure 7. Autoradiograms of $6 \%$ polyacrylamide/urea gels comparing the anti-sense sequences obtained for cDNA; from a normal individual (normal, $A$ ) with the three cDNA species obtained from patient 2557 (largest $=425 \mathrm{bp}, A$; middle $=313 \mathrm{bp}, B$; and smallest $=255$ $\mathrm{bp}, B)$. The amplified product from normal cDNA was $425 \mathrm{bp}$, as expected. The products were acrylamide gel-purified and sequenced directly. The largest $\mathrm{cDNA}$ from patient 2557 displays a $\mathrm{C} \rightarrow \mathrm{T}$ transition at the codon for $\mathrm{PrO}_{417}$ in exon 11 (indicated by * as a G $\rightarrow$ A transition in the antisense sequence). This results in the substitution of a codon for Leu. In this product, exon 10 is correctly spliced to exon $11(A)$. The two smaller products display anomalous splicing. 2557 middle shows exon 10 spliced to a cryptic site midway in exon 11 (at $\mathrm{Asp}_{452}$ ), resulting in a frame-shift with a stop codon. 2557 smallest shows exon 10 spliced to exon 12, to the exclusion of exon 11. This also results in a frame-shift, which introduces a stop codon 171 bases downstream $(A)$.

mRNA (Fig. 7). The two smaller misspliced mRNA species result in premature stop codons that are presumably responsible for their low steady state levels (24-26). The new splice sites identified in Fig. 6 were identical to those identified from cDNA of the Japanese juvenile Sandhoff patient (12).

The genomic DNA from the Japanese patient also encoded a Lys ${ }_{121} \rightarrow$ Arg substitution. COS cell expression studies sug-

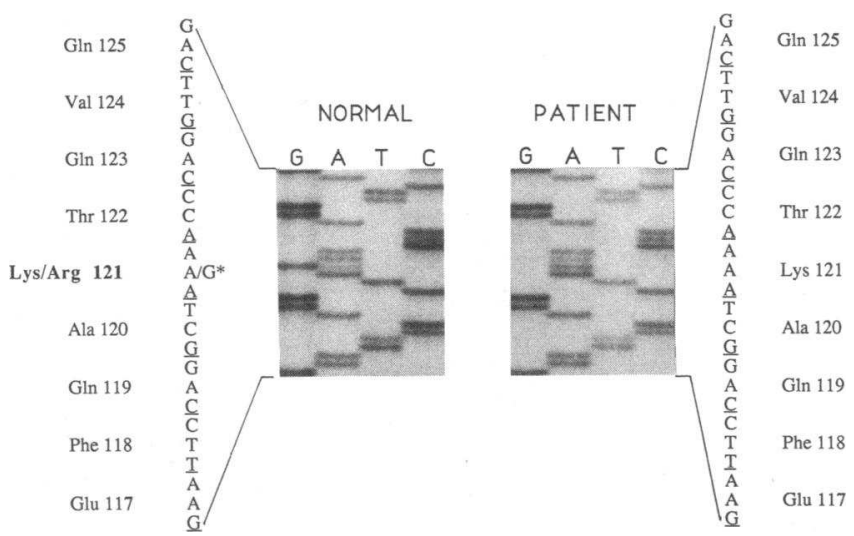

Figure 8. Autoradiogram of a $6 \%$ polyacrylamide/urea gel showing the nucleotide sequence obtained for Normal (R.T) and Patient (2557) genomic DNA in the region of the codon for Lys $_{121}$. Genomic DNA from both sources was amplified in the region of exon 2. In each case, the product was gel-purified and sequenced directly. R.T. is heterozygous for $A \rightarrow G$ substitution at codon 121 (denoted by *), resulting in one allele encoding $\operatorname{Arg}_{121}$ instead of $\mathrm{Lys}_{121}$. The patient's sample contains only the wild type sequence.

gested that it does not affect the transport or function of hexosaminidase B (12). Furthermore, in this report, we showed that the Lys $_{121} \rightarrow$ Arg substitution is present in the normal population. However, we cannot totally rule out the possibility that this seeming polymorphism may exert a very small detrimental effect on the binding the $G_{M 2}$ activator protein $/ G_{M 2}$ ganglioside complex that is only significant in combination with the Pro $_{417}$ Leu substitution; i.e., a cis effect, resulting in the phenotype of the Japanese patient being more severe. This possibility seems unlikely as the residue in question, Lys $_{121}$, is not present in the mature polypeptide (27), amino terminus $\operatorname{Thr}_{122}(28)$, and a Lys $\rightarrow$ Arg substitution should not affect proteolytic processing. It should also be noted that the pro-hexosaminidase A is fully active (29), thus $\mathrm{G}_{\mathrm{M} 2}$ ganglioside hydrolysis can occur with or without the presence of $\mathrm{Lys}_{121}$ in the $\beta$ subunit.

Genomic DNA from our patient did not contain the above Lys $_{121} \rightarrow$ Arg substitution. This demonstrates that the intron $10 /$ exon $11 \mathrm{C} \rightarrow \mathrm{T}$ mutation is present in two different genetic backgrounds and, therefore, probably arose independently in the Japanese and Caucasian populations. The observation that this $C \rightarrow T$ transition affects splicing in exactly the same novel

Table III. Activities of Hexosaminidase Isozymes in an Individual (R.T.) Heterozygous For an $A \rightarrow G$ Transition in Exon 2 of the HEXB Gene Resulting in Conversion of Lys ${ }_{121} \rightarrow$ Arg

\begin{tabular}{|c|c|c|c|c|}
\hline & \multicolumn{2}{|c|}{ Total hexosaminidase activity } & \multicolumn{2}{|c|}{$\%$ Hex B (of total activity } \\
\hline & Serum & Leukocytes & Serum & Leukocytes \\
\hline & $n \mathrm{~mol} / \mathrm{ml}$ per $h$ & nmol/mg per $h$ & & \\
\hline $\begin{array}{l}\text { R.T. } \\
\text { Normal }\end{array}$ & 1130 & 1280 & 25 & 39 \\
\hline range* & $960-1950$ & $1130-2020$ & $24-40$ & $36-43$ \\
\hline
\end{tabular}

* Determined from $n=16$ samples assayed the same day at The Hospital For Sick Children, Lysosomal Storage Disease Laboratory. 
manner in two $H E X B$ alleles from different genetic backgrounds supports the conclusion that this is indeed the cause of the splicing error (thereby precluding the involvement of some other unidentified substitution elsewhere in the allele).

The remaining anomaly is the delayed and mild course of the disease in our patient. On the basis of comparison with the Japanese patient, one would expect our patient to have a more severe phenotype. Biochemical comparisons, such as residual isozyme activities and $\beta$-CRM in cultured fibroblasts were also predictive of a juvenile onset phenotype. The only clinical evidence of Sandhoff disease in our patient was some indication of disturbance of the autonomic nervous system. However, there was direct evidence for $\mathrm{G}_{\mathbf{M} 2}$ ganglioside storage in the observation of MCBs in his intestinal neurons. The same type of MCBs were noted in the Japanese juvenile (12) and the French-Canadian adult onset patients; e.g., cell line 2400 (4). However, the Japanese patient and the adult onset patients had additional clinical symptoms indicating neurological and/or motor neuron involvement (Table I). Furthermore, our patient was not found to excrete detectable amounts of neutral oligosaccharides (data not shown). Both the Japanese patient and the adult Sandhoff patients were shown to excrete large amounts of these compounds $(4,12)$ (Table I). As with 4-MUG hydrolysis, oligosaccharide hydrolysis is primarily accomplished by the active site of the $\beta$ subunit in hexosaminidase A and B (1). Thus, it is even more surprising that our patient does not excrete oligosaccharides given the substantially lower residual hexosaminidase activity and $\beta$-CRM levels found in his fibroblasts, as compared to fibroblasts from the adult onset Sandhoff patient ( Table II). These data suggest that our patient may express variable levels of residual activity in different tissues; i.e., above the critical threshold in most tissues including the brain, kidney, and liver, but below the threshold in others, such as intestinal and other autonomic neurons, and fibroblasts.

The reason for the above variations in phenotypic expression is unclear. One possibility is that tissue-specific differences in our patient, and the overall clinical differences between him and the Japanese patient, could result from small variations in the level of properly spliced $\beta$ subunit-mRNA. The splicing of mRNA involves a large number of gene products (reviewed in [30]) and this mutation is at a site not previously thought to be part of the consensus sequence for splice junctions. It has also been documented that the normal nucleotide sequence at the intron 10 /exon 11 junction in the $H E X B$ gene does not fully conform to the consensus sequence for a splice junction (31). This is consistent with the observation of some $(0.6 \%)$ abnormally spliced $\beta$ subunit mRNA; i.e., P2, in amplified cDNA from normal fibroblasts (12). Many examples of tissue-specific differential splicing of mRNAs have been documented (reviewed in [32]) and it is therefore conceivable that different tissues are able to splice mRNA with this novel substitution better than others. Similarly, there may be small differences in the overall splicing machinery between individuals or between different racial groups. Whereas such differences may normally produce only small variations in a given mRNA level, in this circumstance, their effects could be amplified by the presence of an unconventional splicing mutation coupled with a very small critical threshold of normal $\beta$ subunit translation, $>10$ $20 \%$, necessary to avoid the expression of a Sandhoff phenotype.

Our observations suggest caution to diagnosticians and genetic counselors dealing with lysosomal storage diseases. Resid- ual enzyme activity values in plasma or individual tissues may not accurately reflect the general in vivo activity, particularly when a partial mRNA splicing abnormality is the underlying cause of the decrease in activity. In these cases, even the determination of the patient's genotype may not result in an accurate prediction of the ultimate phenotype.

\section{Acknowledgments}

The authors thank Dr. Pierre Poitras (Hôpital St-Luc, Montréal) and Pr. Modigliani (Hôpital Saint-Lazare, Paris) for providing some clinical data and bringing this case to our attention. We thank Ms. A. Leung for her technical assistance with Fig. 3 and Table II, and Dr. J. Callahan and Ms. M.-A. Skomorowski for the data presented in Table III. We also thank Drs. B. Triggs-Raine, J. Clarke, and R. McInnes for their help in preparing this manuscript.

This work was supported through a grant (MA-10435) from the Medical Research Council of Canada.

\section{References}

1. Kytzia, H.-J., and K. Sandhoff. 1985. Evidence for two different active sites on human $\beta$-hexosaminidase A. J. Biol. Chem. 260:7568-7572.

2. Sandhoff, K., E. Conzelmann, E. F. Neufeld, M. M. Kaback, and K. Suzuki. 1989. The $\mathrm{G}_{\mathrm{M} 2}$ gangliosidoses In The Metabolic Basis of Inherited Disease. C. V. Scriver, A. L. Beaudet, W. S. Sly, and D. Valle, editors. McGraw-Hill Inc., New York. pp. 1807-1839.

3. Mahuran, D. J. 1991. The biochemistry of $H E X A$ and $H E X B$ gene mutations causing $\mathrm{G}_{\mathrm{M} 2}$ gangliosidosis. Biochim. Biophys. Acta. 1096:87-94.

4. Rubin, M., G. Karpati, L. S. Wolfe, S. Carpenter, M. H. Klavins, and D. J. Mahuran. 1988. Adult onset neuronopathy in the juvenile type of hexosaminidase A and B deficiency. J. Neurosci. 87:103-119.

5. Wood, S., and B. G. MacDougall. 1976. Juvenile Sandhoff disease: some properties of the residual hexosaminidase in cultured fibroblasts. Am. J. Hum. Genet. 28:489-495.

6. Conzelmann, E., and K. Sandhoff. 1984. Partial enzyme deficiencies: residual activities and the development of neurological disorders. Dev. Neurosci. 6:5871.

7. Neufeld, E. F. 1991. Lysosomal storage diseases. Annu. Rev. Biochem. 60:257-280.

8. Neote, K., B. McInnes, D. J. Mahuran, and R. A. Gravel. 1990. Structure and distribution of an Alu-type deletion mutation in Sandhoff disease. J. Clin. Invest. 86:1524-1531.

9. O'Dowd, B. F., M. H. Klavins, H. F. Willard, R. Gravel, J. A. Lowden, and D. J. Mahuran. 1986. Molecular heterogeneity in the infantile and juvenile forms of Sandhoff disease (O-variant $\mathrm{G}_{\mathrm{M} 2}$ Gangliosidosis). J. Biol. Chem. 261:12 68012685.

10. Nakano, T., and K. Suzuki. 1989. Genetic cause of a juvenile form of Sandhoff disease: abnormal splicing of $\beta$-hexosaminidase $\beta$-chain gene transcript due to a point mutation within intron 12. J. Biol. Chem. 264:5155-5158.

11. Dlott, B., A. D'Azzo, D. V. K. Quon, and E. F. Neufeld. 1990. Two mutations produce intron insertion in mRNA and elongated $\beta$-subunit of human $\beta$-hexosaminidase. J. Biol. Chem. 265:17 921-17 927.

12. Wakamatsu, N., H. Kobayashi, T. Miyatake, and S. Tsuji. 1992. A novel exon mutation in human $\beta$-hexosaminidase $\beta$ subunit gene affecting the $3^{\prime}$ splice site selection. J. Biol. Chem. 267:2406-2413.

13. Brown, C. A., K. Neote, A. Leung, R. A. Gravel, and D. J. Mahuran. 1989. Introduction of the $\alpha$ subunit mutation associated with the B1 variant of TaySachs disease into the $\beta$ subunit produces a $\beta$-hexosaminidase B without catalytic activity. J. Biol. Chem. 264:21 705-21 710.

14. Bayleran, J., P. Hechtman, and W. Saray. 1984. Synthesis of 4-methylumbelliferyl-beta-D-N-acetylglucosamine-6-sulfate and its use in classification of $\mathrm{G}_{\mathrm{M} 2}$ gangliosidosis genotypes. Clin. Chim. Acta. 143:73-89.

15. Okada, S., and J. S. O'Brien. 1969. Tay-Sachs disease: generalized absence of a $\beta$-D-N-acetylhexosaminidase component. Science (Wash. DC). 165:698700 .

16. Holmes, E. W., and J. S. O'Brien. 1979. Separation of glycoprotein-derived oligosaccharides by thin-layer chromatography. Anal. Biochem. 93:167170.

17. Laemmli, U. K. 1970. Cleavage of structural proteins during the assembly of the head of Bactereophage T4. Nature (Lond.). 227:680-685.

18. Chirgwin, J. M., A. E. Przybyla, R. J. MacDonald, and W. J. Rutter. 1979. Isolation of biologically active ribonucleic acid from sources enriched in ribonuclease. Biochemistry. 18:5294-5299. 
19. Winship, P. R. 1989. An improved method for direct sequencing PCR amplified material using dimethyl sulphoxide. Nucleic Acids Res. 17:1266.

20. Brown, C. A., and D. J. Mahuran. 1991. Active arginine residues in $\beta$-hexosaminidase: identification through studies of the B1 variant of Tay-Sachs disease. J. Biol. Chem. 266:15 855-15 862.

21. Guise, K. S., R. G. Korneluk, J. Waye, A.-M. Lamhonwah, F. Quan, R. Palmer, R. E. Ganschow, W. S. Sly, and R. A. Gravel. 1985. Isolation and expression in Escherichia coli of a cDNA clone encoding human beta glucuronidase Gene (Amst.). 34:105-110.

22. Kaback, M. M., T. J. Nathan, and S. Greenwald. 1977. Tay-Sachs disease: heterozygote screening and prenatal diagnosis-U. S. experience and world perspective In Tay-Sachs Disease: Screening and Prevention. M. M. Kaback, D. L. Rimoin, and J. S. O'Brien. Alan R. Liss Inc., New York, pp. 13-36.

23. Lowden, J. A., M.-A. Skomorowski, F. Henderson, and M. Kaback. 1973. Automated assay of hexosaminidase in serum. Clin. Chem. 19:1345-1349.

24. Takeshita, K., B. G. Forget, A. Scarpa, and E. J. Benz, Jr. 1984. Intranuclear defect in $\beta$-globin mRNA accumulation due to a premature translation termination codon. Blood. 64:13-22.

25. Humphries, R. K., T. L. Ley, A. W. Anagnou, and A. W. Nienhuis. 1984 $\beta^{0}-39$ Thalassemia gene: a premature termination codon causes $\beta$-mRNA deficiency without affecting cytoplasmic $\beta$-mRNA stability. Blood. 64:23-32.

26. Myerowitz, R., and F. C. Costigan. 1988. The major defect in Ashkenazi Jews with Tay-Sachs disease is an insertion in the gene for the $\alpha$-chain of $\beta$-hexosaminidase. J. Biol. Chem. 263:18 587-18 589.
27. Hubbes, M., J. Callahan, R. Gravel, and D. Mahuran. 1989. The aminoterminal sequences in the pro- $\alpha$ and $-\beta$ polypeptides of human lysosomal $\beta$-hexosaminidase A and B are retained in the mature isozymes. Febs (Fed. Eur. Biochem. Soc.) Lett. 249:316-320.

28. Mahuran, D. J., K. Neote, M. H. Klavins, A. Leung, and R. A. Gravel. 1988. Proteolytic processing of human pro- $\beta$ hexosaminidase: identification of the internal site of hydrolysis that produces the nonidentical $\beta_{\mathrm{a}}$ and $\beta_{\mathrm{b}}$ polypeptides in the mature $\beta$-subunit. J. Biol. Chem. 263:4612-4618.

29. Hasilik, A., K. von Figura, E. Conzelmann, H. Nehrkorn, and K. Sandhoff. 1982. Lysosomal enzyme precursors in human fibroblasts. Eur. J. Biochem. 125:317-321.

30.Padgett, R. A., P. J. Grabowski, M. M. Konarska, S. Seiler, and P. A. Sharp. 1986. Splicing of messenger RNA precursors. Annu. Rev. Biochem. 55:1119-1150.

31. Neote, K., B. Bapat, A. Dumbrille-Ross, C. Troxel, S. M. Schuster, D. J. Mahuran, and R. A. Gravel. 1988. Characterization of the human $H E X B$ gene encoding lysosomal $\beta$-hexosaminidase. Genomics. 3:279-286.

32. Smith, C. W. J., J. G. Patton, and B. Nadal-Ginard. 1989. Alternative splicing in the control of gene expression. Annu. Rev. Genet. 23:527-577.

33. O'Dowd, B. F., D. Cumming, R. A. Gravel, and D. Mahuran. 1988. Isolation and characterization of the major glycopeptides from human $\beta$-hexosaminidase: their localization within the deduced primary structure of the mature $\alpha$ and $\beta$ polypeptide chains. Biochemistry. 27:5216-5226. 